\title{
Industrialisasi Pendidikan Tinggi
}

\author{
M. Imam Zamroni \\ Peneliti pada Pusat Studi Asia Pasifik Universitas Gadjah Mada
}

This article aims to describe that the commercialization and industrialization of state higher education are dilemma for government's policy in the era of globalization. On one hand, industrialization increases education expenditures, so that the poor people cannot access it, and on the other hand, it can deliver advantages in the form of welfare for civitas academica and several investors as conducted by developed countries. On the contrary, high education expenditures oppose ambition to realize the Education for All (EFA). Keywords: education, industrialization, commercialization

$\mathrm{K}^{\mathrm{e}}$ etika pendidikan tinggi masih bertumpu pada semangat mulia dengan visi kerakyatan dan tidak menjadikan dunia pendidikan sebagai "ladang bisnis", maka intervensi kapital belum terialu tinggi dan bukan merupakan isu sentral. Aktivitas utama yang dijalankan hanya mengacu pada tiga hal yang tercermin dalam Tri Dharma Perguruan Tinggi_pendidikan, penelitian dan pengabdian kepada masyarakat. Akan tetapi, ketika pemerintah tidak mampu secara penuh menyantuni seluruh kegiatan akademik, pasar bebas merebak, kompetisi bisnis menjadi fenomena dominan di masyarakat dan otonomi kampus dianggap sebagai solusi. Terjadinya otonomi kampus sebenarnya hanya sekedar mengubah dominasi dari tirani negara menuju cengkeraman pasar (Nugroho, 2006:159). Perguruan Tinggi Negeri (PTN) akhirnya dipaksa melakukan derap langkah industrialisasi yang didorong dengan semakin menguatnya arus globalisasi.

Otonomi kampus di dalamnya terdapat semangat desentralisasi sebagaimana yang telah diberlakukan pada pemerintahan lokal kabupaten/kota pasca tumbangnya Orde Baru yang mengandaikan bahwa para elite universitas diberikan kewenangan yang labih luas untuk mengelola dan mengembangkan PTN yang dipimpinnya. Dengan harapan mereka akan lebih mandiri, terutama terkait dengan persoalan pendanaan, namun perlu diketahui bahwa spirit otonomi kampus tidak hanya cuci tangan pemerintah dari faktor pendanaan, tetapi lebih dari itu. Pada posisi inilah PTN kita menghadapi persoalan yang dilematis. Di satu sisi, sebagai sebuah institusi pendidikan dituntut untuk terus meningkatkan kualitas pendidikan sehingga dapat menghasilkan kualitas sumberdaya manusia yang handal, profesional dan memiliki kemampuan kompetitif yang tinggi di tengah krisis ekonomi yang berkepanjangan dan tren pasar bebas yang semakin mengglobal.

Disisi lain, sebagai institusi bisnis diharapkan dapat mendatangkan sejumlah profit demi kesejahteraan sivitas akademikanya,maka yang terjadi kemudian, perguruan tinggi yang terkena status $\mathrm{BHMN}$ akan menawarkan berbagai macam program pendidikan. Tawaran tersebut mulai dari di- 
ploma 1-3, S-1 reguler dan ekstensi, magister kelas biasa dan eksekutif, program S-3, bahkan membuka pelatihan-pelatihan yang bertujuan menggali dana sebanyakbanyaknya agar roda kegiatan dapat eksis dalam upaya menjalankan administrasi dan peningkatan kesejahteraan sivitas akademikanya. Akibatnya, terdapat kecenderungan bahwa tidak akan ada lagi PTN yang menyediakan biaya murah bagi mereka yang tidak mampu.

Dalam perjalanannya kebijakan otonomi kampus banyak mengalami ketimpangan, dan bahkari cenderung berat sebelah. Komersialisasi dan industrialisasi pendidikan tinggi lebih mengemuka daripada terciptanya kemandirian pengelolaan perguruan tinggi dan pendanaan. Sehingga pemerintah memberikan kesempatan yang seluas-Juasnya untuk menggalakkan pencarian dana mandiri lewat berbagai program pendidikan yang "laku jual" akibat kebijakan "swastanisasi" (Nugroho, 2002:4) yang kemudian mengarah pada privatisasi. Privatisasi secara umum cenderung dipahami sebagai sebuah proses sistematis untuk memindahkan status kepemilikan BUMN atau kekayaan publik lainnya dari tangan seluruh anggota masyarakat kepada para pemilik modal perseorangan (Baswir, 2003:206).

Berawal dari situlah, nafas deru pendidikan tinggi saat ini tak ubahnya seperti industri yang bergerak dengan prinsip kuantifikasi, efisiensi, keterprediksian dan teknologisasi (Nugroho, 2002:13). Tarif pendidikan tinggi negeri meningkat tajam yang mengakibatkan rakyat kecil semakin sulit mengaksesnya karena himpitan biaya yang tidak terjangkau oleh kelompok mayoritas itu dan akhirnya kelompok-kelompok kecil seperti petani, buruh, masyarakat miskin dan pengangguran akan "tertelan" kelompok-kelompok yang telah digdaya secara kapital dan kelompok miskin selalu menjadi bagian dari piramida pengurbanan menusia (Berger, 2004:37). Kaum lemah tersebut "terpinggirkan" oleh sistem yang tidak berkeadilan sosial yang diciptakan secara sistemis oleh kekuasaan negara.

Komersialisasi dan industrialisasi pendidikan tinggi sebenamya bukan hal yang baru di Tanah Air. Jauh sebelum kebijakan otonomi kampus digulirkan dan dituangkan dengan peraturan pemerintah yang menetapkan universitas negeri berubah posisi menjadi Badan Hukum Milik Negara (BHMN), komersialisasi pendidikan tinggi sudah banyak dilakukan oleh perguruan tinggi swasta. Memang harus diakui, meski komersialisasi melanda pendidikan tinggi swasta, beberapa di antaranya memang bonafit. Mereka mempunyai keunggulan karena didukung sumber daya yang andal, yayasan yang kukuh, serta komitmen pada pengabdian bangsa yang kuat, meski pada sektor pembiayaan mereka relatif lebih mandiri. Implikasi teoritis yang ditimbulkan, pendidikan tinggi swasta yang bonafit selalu mensyaratkan biaya yang tinggi bagi mahasiswanya.

Meski pada awainya niatan pemerintah mem-BHMN-kan PTN tidak hanya berupa pengurangan subsidi pendanaan, tetapi yang dirasakan oleh rakyat adalah menggelembungnya biaya pendidikan yang menjadikan PTN semakin tidak terjangkau oleh rakyat kecil. Padahal semula, PTN merupakan satu-satunya lembaga pendidikan yang dapat diandalkan oleh kelompok miskin, karena faktor pembiayaan yang relatif dapat terjangkau, namun realitas telah berbalik arah. Bayangkan jika seorang calon mahasiswa yang akan masuk saja saat ini sudah tidak berkompetisi dengan kemampuan akademik atau prestasi yang gemilang, namun mereka harus bertarung 
melawan kekuatan kapital. Besaran kapital lebih menjanjikan seseorang diterima di perguruan tinggi yang bonafit daripada prestasi akademik yang gemilang, dengan dana Rp 15 juta-Rp 150 juta seseorang akan lebih leluasa menentukan perguruan tinggi yang diinginkannya. Jelas sudah bahwa, nalar yang digunakan dalam PTN telah terseret pada logika industrial, dimana kekuasaan kapital menjadi amat menentukan segala sesuatu yang diinginkan seseorang. Dalam perdebatan di World Trade Organization (WTO), pendidikan menjadi bagian komoditas yang diperdagangkan, ironisnya pemerintah kita sama sekali belum siap dengan wacana yang telah marak berkembang di belahan negara-negara maju. Hal ini tercermin pada ketidakadaannya aturan yang jelas terkait dengan isu yang terus mengglobal dan tak bisa dibendung lagi dengan kekuatan apapun yang dimiliki negara.

Bersamaan dengan itu, akibat persaingan yang semakin mengglobal terdapat - pergeseran-pergeseran di dunia pendidikan. Saat ini program studi yang paling diminati mahasiswa adalah program studi yang berorientasi pada kebutuhan lapangan , pekerjaan seperti kedokteran, teknik industri, dan ekonomi sedangkan program studi ilmu sosial, budaya dan filsafat bukanlah menjadi pilihan utama karena tidak dapat menjanjikan lapangan pekerjaan yang pasti.

Ekses negatif yang ditimbulkan mereka hanya mahir menjalankan instruksi teknis dan bukannya berpikir kritis dan reflektif terhadap problematika sosial yang dihadapi bangsa Indonesia yang kian kompleks. Karena proses pendidikan di kampus hanya dipersiapkan untuk dunia kerja, bukan untuk menciptakan kemandirian sosial maupun peningkatan kualitas diri. Tak heran jika nalar pragmatisme semakin merebak disetiap lini kehidupan. Logika link and match antara pendidikan dan dunia kerja semakin deras menjangkiti pola pikir masyarakat kita. Akibat semakin menguatnya liberalisasi, hampir semua orang "dipaksa" untuk turut serta memenuhi kebutuhan pasar. Ini artinya filsafat pendidikan pada akhirnya tidak bisa dipisahkan dari filsafat kebudayaan yang lebih luas di mana pendidikan menjadi bagian yang mencerminkan arus besar yang melingkupinya (Kleden, 1996:11).

Arus besar liberalisasi di era globalisasi yang telah merambah negara-negara dunia ketiga, termasuk Indonesia, mengharuskan untuk tunduk dan patuh pada kekuasaan pasar yang semakin digdaya. Dalam satu dekade terakhir, gejala liberalisasi pendidikan tinggi juga semakin menguat seiring dengan diberlakukaninya swastanisasi perguruan tinggi negeri yang kemudian mengarah pada industrialisasi. Agar perguruan tinggi tetap "survive" mereka harus menggali pendanaan secara mandiri yang berakibat semakin tingginya biaya pendidikan. Pendidikan tinggl akhimya tidak dapat dinikmati oleh semua lapisan sosial masyarakat.

\section{Liberalisas| Pendldikan}

Anggapan dasar liberalisme menginginkan perubahan yang mendasar dan perombakan dengan cepat dalam ruang lingkup yang besar terhadap tatanan sosial yang ada sekarang demi memperbesar kebebasan individual serta memromosikan perwujudan potensi personal secara maksimal (O'neil, 2002:358). Mereka juga ingin membatasi campur tangan pemerintah dalam bidang ekonomi yang menganut paham laissez-faire, mengembangkan kebebasan individu (personal liberty), terus memperbanyak kepemilikan pribadi ( $p r i v a t e$ property), dan memberikan ruang yang lebih 
luas kepada sektor usaha swasta (private interprise) (Fakih,2002:46). Pemberlakukan BHMN terhadap perguruan tinggi negeri di Indonesia sama halnya dengan menswastanisasikan institusi pendidikan tinggi negeri dengan berbagai macam konsekuensi yang melingkupinya.

Rupanya perdebatan liberalisasi pendidikan yang mengkategorikan pendidikan sebagai salah satu komoditas jasa yang dikomersialkan (commercial service) telah diimplementasikan di negara-negara maju, seperti Australia, Selandia Baru, Inggris, dan AS. Bahkan negara-negara maju itu menganggap bahwa trade in educational service sudah menjadi ajang bisnis yang menjanjikan yang telah dirintis kurang lebih selama 10 tahun terakhir. Dalam laporan World Trade Organization (WTO) mengatakan, pada tahun 2003, "industri pendidikan" telah menyumbang 30 milyar dollar AS dan diramalkan akan terus meningkat seiring dengan liberalisasi pendidikan yang semakin menguat di seluruh dunia.

Perguruan tinggi dinegara-negara maju telah menggunakan nalar bisnis, maka mereka tidak menunggu datangnya "pembeli", akan tetapi "menjem-put bola" dengan membuka cabang universitas diberbagai negara dengan logika mengekspor komoditas jasa pendidikan ke negeri orang. Seperti Nottingham University dari Inggris yang mendirikan kampus satelit di Malaysia dan juga membuka cabang di Shanghai, China, dengan menggandeng rekanan dari China dan mendirikan kampus yang luasnya mencapai 38 hektar. Di kampus ini bahkan didirikan semacam replika dari gedung pusat Nottingham University yang neoklasik (Kompas, 24/07/ 2007). Tak heran kalau sejak tahun 2000 jumlah kampus satelit di seluruh dunia berkembang dua kali lipat menjadi sekitar 80 buah. Pemain utamanya masih diperan- kan oleh Amerika, karena saat ini Amirika yang paling banyak memiliki universitas terbaik di dunia.

Industri pendidikan tinggi di berbagai belahan negara-negara maju telah berkembang sedemikian pesat. Akan tetapi Indonesia masih berkutat pada masalah klasik di bidang pendanaan dan pemertahanan kualitas. Memang akibat kebijakan otonomi PTN telah mendorong untuk turut "menjemput bola" dengan membuka cabang di berbagai wilayah pelosok di Indonesia. Namun jika kita melihat realitas yang ada, pembukaan cabang tersebut sangat memprihatinkan, karena peningkatan kualitas manusia seutuhnya bukanlah menjadi prioritas utama dalam penyelenggaraan perguruan tinggi di daerah terpencil, akan tetapi hanya melulu mengejar gelar akademik yang berorientasi pada persoalanpersoalan pragmatis, seperti pangkat dan jabatan dalam pekerjaan yang mereka sandang. Pola pikir seperti ini harus segera dirombak.

Terkait dengan liberalisasi pendidikan, pemerintah harus mempunyai aturan yang jelas dalam perdagangan jasa pendidikan (educational trade servives). Pendidikan tinggi dimaksudkan untuk menyediakan jasa publik, dan bukan komoditas yang diperdagangkan. Jika trade in educational services diterapkan, cepat atau lambat pendidikan di Indonesia akan menjadi lahan industri empuk bagi para pemodal dan WTO berhak menerapkan aturan-aturan tertentu terkait dengan komoditas jasa pendidikan, tidak hanya itu, peran pemerintah di bidang pendidikan akan semakin "kerdil". Hal ini bertentangan dengan semangat untuk menciptakan Education For All (EFA), karena masyarakat kecil akan semakin sulit menikmati pendidikan yang berkualitas, segala sesuatu berada di bawah cengkeraman "kekuasaan pasar". Pendidikan 
tinggi seolah menjadi barang mewah yang hanya dapat dinikmati oleh kaum berkantong tebal, sedangkan kelompok yang tergolong miskin akan tetap stagnan pada kondisi yang memprihatinkan.

Agar sektor pendidikan terlepas dari aturan WTO, maka sebaiknya penyelenggaraan pendidikan diusahakan agar kegiatan sektor pendidikan bukan kegiatan yang dikategorikan sebagai commercial services dan membatasi lembaga pendidikan asing yang beroperasi di dalam negeri agar tidak terjadi trade services bidang pendidikan. Dengan demikian, kalau ada lembaga pendidikan asing yang beroperasi di dalam negeri, meraka harus diatur menurut aturan yang jelas soal legalitas, sertifikasi, akreditasi, kurikulum dan sejenisnya agar ada batasan yang tegas apakah pendidikan yang dikelola lembaga asing itu masuk kategori educational trade services atau tidak. Bila masuk, mereka akan terkena aturan WTO tersebut.

Paling tidak, aturan tersebut di atas dapat dimasukkan dalam Undang-Undang Sistem Pendidikan Nasional (UU SISDIKNAS). Agar pemerintah dapat mengambil sikap yang jelas dan memposisikan diri terkait dengan ketetapan WTO akibat arus liberalisasi pendidikan tinggi yang semakin mengakar kuat di Indonesia. Dalam konteks kompetisi global dan upaya untuk meningkatkan kualitas pendidikan dengan berkaca pada negaranegara maju, liberalisasi pendidikan tidak perlu dikhawatirkan. Akan tetapi, dalam konteks pengelolaan dan kelestarian nilainilai tradisi budaya bangsa sebagai identitas dalam percaturan global, kita harus mengambil langkah yang kreatif dan inovatif bahkan tidak menutup kemungkinan melakukan tindakan protektif terhadap derasnya arus budaya manca demi kelestarian budaya bangsa.
Hal ini didasarkan pada asumsi bahwa, pendidikan tidak hanya sekedar transformasi ilmu pengetahuan (transformation of knowledge), tetapi juga mentransformasikan nilai-nilai dan ideologi (transformation of values and ideology) yang akan menjadikan seseorang lebih mengenal jatidirinya sebagai bangsa Indonesia dan menumbuhkan nasionalisme. Nasionalisme merupakan ruh kekuatan nasional untuk mengeluarkan bangsa ini dari keterbelakangan, kebodohan dan kemiskinan.

\section{Sangkar Besi Industrialisas! Pendidikan. Tinggi}

Industrialisasi pendidikan tinggi yang berpijak pada pola pikir kalkulatif dan mengedepankan pada pengejaran ekonomi semata telah terperosok dalam sangkar besi kekuasaan pasar. MaxWeber mengatakan bahwa industrialisasi yang menerapkan prinsip-prinsip rasionalisasi dan teknologisasi di berbagai bidang telah menghasilkan fenomena disenchantment of the world, yaitu suatu proses memudarnya pesona dunia karena segala hal yang ada di buml ini dapat dikalkulasi secara rasional. Akibat yang ditimbulkan dari rasionalisasi adalah terjadinya penurunan kualitas kehidupan manusia atau dehumanisasi, karena segala hal yang sebelumnya bersifat subyektif dapat diubah menjadi obyektif, yang kualitatif menjadi kuantitatif (Nugroho, 2002:10).

Hilangnya pesona dunia modern, berarti sistem keyakinan yang sebelumnya merupakan sebuah kekuatan yang mengubah kehidupan sosiai secara revolusioner, mengurangi peran yang dimainkannya. Pada saat yang sama, keuntungan-keuntungan darl meningkatnya pengetahuan dan penguasaan mengenai lingkungan alamiah. Dominasi dunia alamiah ini pada akhirnya 
diletakkan pada asumsi dasar sentral menguasai penelitian ilmiah, yaitu bahwa seluruh realitas itu pada akhirnya bisa diketahui atau dikalkulasi. IImu pengetahuan menyampaikan teknik penentuan cara yang paling efisien untuk mencapai tujuan tertentu di seluruh bidang kehidupan intelektual (Schroeder, 2002:17). Industrialisasi PTN juga dianggap sebagai cara yang paling efisien oleh pemerintah karena beban pembiayaan yang terlalu berat.

Berkaca dari tesis Weber, di dunia pendidikan tinggi kekuatan pasar telan menggeser peran pemerintah yang semula amat dominan. Ini sama halnya dengan keluar dari mulut buaya masuk ke mulut harimau, pendidikan tinggi tak pernah terbebas dari persoalan sosial politik yang melingkupinya. Dalam cengkeraman pasar yang semula mengandaikan kebebasan untuk lebih leluasa dalam mengembangkan perguruan tinggi, justru malah sebaliknya mereka terjebak dalam berbagai macam problematika, akhirnya pendidikan tinggi negeri terbelenggu dalam sangkar besi industrialisasi. Hal yang tidak kalah penting bahwa, keberpihakan perguruan tinggi terhadap kehidupan rakyat kecil terus mengalami degradasi, karena telah masuk dalam cengkeraman pasar, PTN tidak mampu lagi memerankan visi mulia itu.

Ketika perguruan tinggi, baik negeri maupun swasta, terseret arus besar industrialisasi, yang menjelma dalam komodifikasi pendidikan, maka mereka juga tidak luput masuk ke dalam dilemma industrial. Perguruan tinggi bisa menggali pendanaan lokal dengan menjual jasa pendidikan kepada masyarakat secara cepat dan menguntungkan, namun disisi lain di dalam PT itu sendiri terjadi degradasi kualitas pendidikan. Atau mempertahankan kualitas pendidikan namun kesulitan dalam pengadaan pendanaan pendidikan. Supaya pendidikan tinggi bisa cepat "dipasarkan", maka mereka harus merumuskan pendidikan yang cepat saji, cepat disantap oleh konsumen, cepat berproduksi lagi, cepat menciptakan kesejahteraan. Maka terjadilah apa yang dinamakan "Mcdonaldisasi pendidikan tinggi" (Nugroho, 2002).

Mcdonaldisasi pada sektor pendidikan tinggi ternyata telah menciptakan sangkar besinya sendiri, yaitu pertumbuhan, kuantifikasi, dan keharusan memproduksi sebanyak-banyaknya. Serta logika pasarpun merasuk dalam tubuh perguruan tinggi dengan membuka program studi-program studi yang mampu mendatangkan mahasiswa sebanyak-banyaknya. Mcdonaldisasi pendidikan pada awalnya memang bermula dari sesuatu yang rasional, yaitu otonomi kampus, namun berakhir dengan irasionalitas, yaitu dehumanisasi, penurunan kualitas pendidikan tinggi dan komersialisasi pendidikan tinggi. Maka terjadilah perlombaan pengumpulan dana masyarakat oleh PTN demi untuk memenuhi biaya operasional pendidikan yang semakin tinggi. PTN ibarat keluar dari tirani kekuasaan negara masuk pada cengkeraman pasar berupa menginstitusikan lembaga pendidikan menjadi lembaga bisnis.

Pada masa sebelum terjadi ekspansi pasar di berbagai bidang kehidupan, pendidikan dipandang sebagai lembaga mulia yang akan menelurkan manusiamanusia yang berkualitas. Namun saat ini pendidikan tinggi negeri telah masuk pada cengkeraman pasar, sebagaimana yang dikatakan oleh Charles Lindblom (1977:ix) ...the operation of parlements and legislatives bodies, bureaucraties, parties, and interest groups depends in large part on the degree to which goverment replaces market or market replace govemment... pasar terus melakukan ekspansi secara besar-besaran dan mempolarisasi peran 
negara. Proteksi kepada pendidikan tinggi berupa subsidi menjadi suatu keharusan bagi negara, baik kepada pendidikan tinggi negeri maupun swasta, agar pendidikan yang berkualitas dapat dinikmati oleh semua kalangan.

Pergeseran pendidikan tinggi negeri yang semula bersifat egaliter dan tidak memihak kepada kelas sosial tertentu, secara tidak langsung telah berubah menjadi elitisme. Pendidikan sekarang hanya mampu diakses oleh kaum the upper class, dan mereka yang tergolong the lower class akan tetap pada jalur kemiskinan dan hidup serba kekurangan. Kalau dianalisis secara mendalam, pendidikan, kita seperti telah kembali pada masa penjajahan kolonial Belanda, di mana pendidikan pada masa itu hanya diperuntukkan pada kaum ningrat (kelompok priyayi) atau kelompok bangsawan yang mempunyai status sosial tinggi (Latif, 2005:97), sedangkan rakyat pribumi tidak mempunyai hak untuk mengakses pendidikan yang mengakibatkan mereka terus taken for granted terhadap situasi dan kondisi yang diciptakan oleh penjajah. Akhirnya terjadi disparitas yang amat tajam antar kelompok status sosial ekonomi dan kesenjangan antar wilayah geografis. Setelah satu dekade memasuki era reformasi, disparitas kian menganga yang terkadang juga memicu munculnya konflik horizontal.

Kalau zaman dahulu memang kebijakan kolonial tidak pernah berpihak pada rakyat jelata, tentu berbeda dengan masa sekarang, mereka dengan leluasa dapat memilih pendidikan yang diinginkan, namun harus mampu membayar biaya pendidikan yang terus melambung, akhirnya kelompok kecilpun tak kuasa untuk menikmati pendidikan tinggi. Kalau zaman dahulu tekanan terhadap rakyat jelata tersebut dilakukan oleh penjajah, akan tetapi di era globalisasi ini tekanan terhadap rakyat kecil tersebut dilakukan oleh kekuatan pasar. Masuknya kekuatan pasar, budaya korporasi, dan kekuatan industri akan merubah misi pendidikan tinggi. Etika dan moral di dunia pendidikan tinggi dikuasai oleh etika dan moral bisnis yang berdasarkan mencari keuntungan dan efisiensi. Akuntabilitas pendidikan tinggi yang diagung-agungkan menjadi akuntabilitas dari pemegang modal.

Kondisi itu sebenarnya tidak jauh berbeda dengan pola pendidikan yang digagas oleh Snouck Hurgronje sebagai wujud dari pemberlakuan politik etis di Indonesia yang dilaksanakan secara otoriter dan tiranik. Namun akibat liberalisasi dalam berbagai bidang, gagasan Snouck Hurgronje telah 'berubah wajah' menjadi elitisme pendidikan. Yang perlu digarisbawahi yaitu walaupun latar belakang yang menyebabkan keterpurukan dunia pendidikan itu berbeda, namun ekses yang ditimbulkan tidak jauh berbeda, pendidikan masih berpihak pada kaum yang berkantong tebal atau orangorang kaya. Hal ini berakibat pada, pembangunan kualitas sumber daya manusia (Human Development Index/HDI) sebagai modal utama merosot tajam dalam beberapa tahun terakhir. Pada tahun 1997 peringkat HDI Indonesia menduduki ke 99 , sedangkan tahun 2002 peringkat ke-102, tahun 2004 peringkat ke-111, tahun 2005 peringkat ke110 , dan tahun 2007 peringkat ke-107 (Kompas, 10/12/2007).

Disisi lain, data Badan Pusat Statistik memberi gambaran jumlah anak putus sekolah masih sangat besar dibandingkan mereka yang bisa terus melanjutkan ke jenjang lebih tinggi. Berdasarkan penelitian tahun 1994 sampai tahun 1998, ternyata pencapaian kelulusan hanya 26,39 persen untuk perempuan dan 30,57 persen untuk laki-laki (Kompas, 8/09/2000). Artinya hanya sepertiga peserta didik yang bisa 
meneruskan sekolah, dan dua pertiganya putus sekolah. Kenyataan ini sekaligus menunjukkan beratnya daya dukung ekonomi masyarakat untuk menopang kegiatan pendidikan. Yang terjadi kemudian, anak putus sekolah ini masuk dalam pasar kerja, demi alasan membantu ekonomi orangtua. Anak harus bekerja sebelum kedewasaan psikologis sosial dan fisiknya memungkinkan. Inilah ironi sebuah kegiatan belajar-mengajar yang gagal, karena minimnya daya dukung okonomi.

Melihat problematika di atas penulis berpendapat, bahwa pemerintah perlu memberikan anggaran pendidikan yang sepadan dengan kondisi riil bangsa indonesia yang sedang terkena penyakit krisis moneter berkepanjangan, agar pendidikan tidak hanya dapat dinikmati oleh segelintir orang saja yang tergolong mampu secara sosial ekonoml, namun pendidikan merupakan hak setiap orang yang harus dapat dinikmati oleh seluruh rakyat Indonesia dan mempunyal kesempatan yang sama, sehingga kompetisi dalam dunia pendidikan akan semakin 'sehat', yang didasarkan oleh kemampuan intelaktual dan bukan kemampuan kapital. Upaya untuk terus menciptakan pendidikan yang berbasis kerakyatan merupakan gagasan cemerlang yang harus direalisasikan secara berkelanjutan, agar dapat mengikis feodalisme pendidikan atau elitisme pendidikan yang semakin kuat memasuki negara Indonesia.

\section{Menguatkan Kapasitas Negara}

Sepanjang pemerintah berpihak kepada kekuatan-kekuatan neoliberal, maka yang terjadi adalah semakin terkikisnya peran negara untuk mencerdaskan kehidupan masyarakat. Kekuatan neoliberal itu terdiri dari empat aspek yakni, mendorong kekuatan individu, mendorong mekanisme pasar, masyarakat diiming-imingi program karikatif, pasar dianggap sebagai pengambil keputusan paling bijaksana. Indikator tersingkirnya peran negara dapat kita lihat jika masyarakat berteriak akan dua hal yakni, mahalnya biaya pendidikan dan mahalnya biaya kesehatan. Saat ini angka partisipasi di perguruan tinggi (Gross Enrolment Rates/GER) hanya 16 persen sangat rendah dibandingkan dengan negara-negara tetangga, dengan proporsi anak keluarga miskin hanya 1 persen, sementara anakanak darikeluarga lebih mampu hampir 50 persen.

Menyaksikan kecenderungan yang terjadi, masalahnya bukan terletak pada menolak atau mendukung, melainkan yang penting adalah melihat kemball apakah industrlalisasi pendidikan membawa keadaan Indonesia kepada keadaan yang lebih baik atau malah semakin buruk. Sebab, kadang-kadang bentuk industrialisasi pendidikan kita ambil sepotongsepotong sesuka kita. Implikasi jangka panjang dari globalisasi pendidikan tinggi belum sepenuhnya dapat diperkirakan. Karena itu, kebijakan-kebijakan antisipatif perlu dirancang secermat mungkin agar globalisasi tidak sampai menghancurkan sektor pendidikan tinggi seperti yang terjadi dengan globalisasi sektor pertanian. Saat ini, Indonesia telah "dibanjiri" dengan universitas-universitas asing dari negara-negara maju yang terus melebarkan sayapnya di negara-negara sedang berkembang, tak ubahnya seperti pendirian industri yang semakin marak dalam beberapa tahun terakhir.

Kakuatan negara dalam hal ini bukanlah untuk reintervensl terhadap otonomi pendidikan tinggi yang sudah diterapkan selama beberapa tahun terakhir. Karena hal itu akan menyebabkan perguruan tinggi semakin tidak mandiri dalam melakukan inovasi-inovasi dan pengembangan ilmu 
pengetahuan. Namun intervensi pemerintah berupa pemberian subsidi dan kebijakan terkait dengan politik perdagangan internasional yang diprakarsai oleh WTO dengan menjadikan pendidikan sebagai komoditas yang diperdagangkan. Dengan cara ini kualitas pendidikan tinggi akan terus meningkat. Terlebih di era liberalisasi pendidikan ini peningkatan kualitas menjadi suatu keharusan, karena dalam beberapa tahun terakhir kualitas pendidikan kita mengalami penurunan di tengah kemajuan dan perkembangan dunia modern yang semakin cepat.

Kenyataan ini tergambar dalam indeks pembangunan pendidikan atau EDI (Educational Development Index) yang terdapat pada laporan EFA (Education For All) yang dipublikasikan dalam Global Monitoring Report 2008. Dalam laporan tersebut menyebutkan, posisi Malaysia melonjak enam tingkat dari peringkat 62 menjadi 56. Sebaliknya peringkat Indonesia turun dari posisi 58 menjadi 62 . Nilai total EDI yang diperoleh Indonesia juga turun 0,003 poin, dari 0,938 menjadi 0,935. Sementara itu, Malaysia berhasil meraih total nilai 0,945 atau naik 0,011 poin dari tahun sebelumnya (Kompas, 31/12/2007). Padahal kita tahu bahwa Malaysia pernah "berguru" pada Indonesia dalam bidang pendidikan. Dengan melihat prestasi pendidikan Indonesia yang kian merosot, haruskah kita terus berpangku tangan dan mempercayakan dunia pendidikan pada kemampuan dan kekuatan pasar? Tentu jawabnya tidak, peran negara menjadi amat penting dalam hal ini.

Para elite kita harus berkomitmen untuk merealisasikan anggaran pendidikan sebesar 20 persen karena dalam realitasnya masih jauh dari target. Berdasarkan mandat UUD 1945 yang dipertegas dengan UU No. 20/2003 mengenai Sisdiknas menekankan alokasi anggaran 20 persen dari APBN dan
APBD yang tidak termasuk gaji guru. Namun kenyataan berkata lain, pada tahun 2005 pemerintah pusat hanya mengalokasikan 8,1 persen, sedangkan pada tahun 2006 alokasi anggaran sebesar 9,4 persen atau sebesar Rp 44,1 trilyun dari total belanja APBN termasuk untuk gaji guru, sedangkan pada tahun 2007 anggaran sebesar 11,8 persen atau sebesar Rp 90,10 triliun (Kompas, 10/12/2007). Berdasarkan data di atas tentunya realisasi anggaran untuk pendidikan masih sangat jauh dari amanat 20 persen dan jika tidak dilakukan reformasi di dunia pendidikan, niscaya Indonesia tidak akan pernah siap menghadapi arus besar liberalisasi pendidikan, padahal mau tidak mau, suka atau tidak suka, cepat atau lambat, liberalisasi pendidikan adalah suatu keniscayaan yang harus dipersiapkan sejak dini.

Para pemimpin dan elite birokrasi harus mempunyai komitmen yang tinggi untuk memprioritaskan dunia pendidikan dalam program pembangunan. Memprioritaskan pembangunan pada sektor pendidikan merupakan bagian dari investasi jangka panjang dalam menghadapi persaingan yang semakin mengglobal. Disisi lain sektor pendidikan merupakan urat nadi peningkatan kualitas sumber daya manusia. Dalam kancah persaingan global modalitas yang paling penting dalam pembangunan di suatu negara adalah modal manusia (human capita) dan tidak lagi mengandalkan pada sektor alam (natural resources). Di Indonesia, kekayaan alam telah dieksploitasi secara besar-besaran yang menyebabkan terjadinya ketimpangan ekologis yang sangat mengkhawatirkan, banjir, tanah longsor, dan bencana alam lainnya menjadi bukti nyata dari eksploitasi yang tidak memperhatikan kelestarian ekologis.

Tentunya kita harus yakin bahwa, problematika yang dihadapi bangsa ini 
bermuara pada pendidikan yang semakin mengalami kemunduran di tengah dunia yang terus bergerak cepat. Akhirnya, semua memang tergantung komitmen, visi dan kemauan politik para pemimpin negara ini untuk membangun pendidikan di indonesia. Tidak sedikit negara yang lebih miskin dari Indonesia mampu mengalokasikan anggaran lebih besar dari Indonesia. Semua negara yang maju dalam hal ekonomi adalah negaranegara yang menempatkan pendidikan sebagai prioritas pembangunan-nya.

\section{Penutup}

Ketertinggalan Indonesia terjadi tidak hanya pada pendidikan dasar, menengah atau lanjutan, tetapi juga di pendidikan tinggi yang mendorong pemerintah mengeluarkan kebijakan-kebijakan untuk pengembangan di sektor tersebut. Dalam iklim perekonomian global seperti sekarang ini pendidikan tinggi dan inovasi merupakan suatu keharusan yang tidak bisa ditawar-tawar lagi untuk memenangkan dalam persaingan global. Ketertinggalan dalam beberapa bidang itu akan membuat negara atau perekonomian bersangkutan tidak akan mampu bersaing dengan negara-negara lain yang bergerak lebih cepat dalam menangkap peluang dan mengatasi tantangan.

Akibat liberalisasi pendidikan, tantangan yang harus dihadapi oleh perguruan tinggi, baik negeri maupun swasta, menjadi semakin kompleks. Industrialisasi dan komersialisasi pendidikan tinggi merupakan peluang dan sekaligus tantangan yang harus dihadapi oleh para pemimpin bangsa dan masyarakat pada umumnya. Industrialisasi pendidikan tinggi membuka peluang bisnis yang amat menjanjikan bagi pada pemodal dan investor sebagaimana yang telah di lakukan oleh negara-negara maju. Namun, industrialisasi pendidikan tinggi juga menyisakan per- soalan-persoalan yang amat pelik bagi masyarakat kita terutama terkait dengan faktor pendanaan dan biaya pendidikan yang semakin membumbung tinggi mengingat angka partisipasi masyarakat dalam pendidikan tinggi hanya 16 persen. Rendahnya angka partisipasi masyarakat dalam pendidikan tinggi juga disebabkan oleh ketidakterjangkauan pembiayaan.

Kita boleh saja berargumentasi dan mendorong pemerintah untuk mengadopsi sistem pendidikan yang diterapkan di negara-negara maju. Tetapi perlu diingat, bahwa di negara-negara maju tersebut, jaminan sosial (social security) telah terbangun dengan baik sehingga dapat menciptakan kesejahteraan sosial (social welfare) bagi warganya, sedangkan Indonesia masalah kesejahteraan sosial bagi seluruh masyarakat masih jauh dari harapan. Oleh karena itu, kebijakan pembangunan di dunia pendidikan harus berbasis keadilan sosial (social justice) dengan menerapkan prinsip-prinsip pendidikan untuk semua (education for all).

Berangkat dari kita harus memikirkan kembali kebijakan pemerintah terkait dengan komersialisasi dan industrialisasi pendidikan tinggi, apakah dapat meningkatkan kesejahteraan sosial dan keadilan sosial bagi masyarakat atau malah justru sebaliknya, menciptakan marginalisasi secara sistemis bagi kaum miskin karena ketidakterjangkauan biaya pendidikan yang semaki mahal?. Padahal kita tahu bahwa, spirit pendidikan tinggi negeri semula merupakan pendidikan yang berpihak dan memberikan kesempatan yang seluasluasnya kepada kelompok miskin yang jumlahnya masih sangat dominan di bumi nusantara ini. Tentunya hal itu bertentangan dengan semangat mulia untuk menciptakan pendidikan yang dapat dinikmati oleh semua kalangan, demi terciptanya bangsa yang 
berkarakter dan berkualitas untuk menghadapi kompetisi global yang semakin menguat.

\section{Daftar Pustaka}

Bastian, Aulia Reza. 2002. Reformasi Pendidikan;Langkah-Langkah Pembaharuan dan Pemberdayaan Pendidikan Dalam Rangka Desentralisasi Sistem Pendidikan Indonesia, Yogyakarta: Lappera.

Baswir, Revrisond. 2003. Privatisasi BUMN; Menggugat Model Ekoniomi Neo-liberal IMF, dalam I. Wibowo dan Francis Wahono (ed), Neoliberalisme. Yogyakarta: Cindelaras Pustaka Rakyat Cerdas.

Berger, Peter L. 2004. Piramida Kurban Manusia; Etika Politik dan Perubahan Sosial. Jakarta: LP3ES.

Fakih, Mansour. 2002. Runtuhnya Teori Pembangunan dan Globalisasl, Yogyakarta: Pustaka Pelajar.

Kleden, Ignas, 1996, Lingking dan Delingking Dalam Pendidikan dan Kebudayaan; Mempertanyakan Konsep Link dan Match, dalam majalah BASIS No.03-04 tahun ke-45 Mei-Juni, 1996

Latif, Yudi. 2005. Intelegensi Muslim dan Kuasa; Geneologi Intelegensia Muslim Indonesia Abad $k \theta-20$. Bandung: Mizan
Lindblom Charles E. 1977. Politics and Markets; the Worl's Political Economic Systems. New York: Basic Book, Inc., Publishers

Nugroho, Heru. 2006. Ekonomi Politik Pendidikan Tinggi: Universitas Sebagai Arena Perebutan Kekuasaan, dalam Vedi $R$ Hadiz dan Daniel Dhakedae (ed), IImu Sosial dan Kekuasaan di indonesia. Jakarta: Equinox Publishing Indonesia

Nugroho, Heru. 2002. Mcdonalisasi Pendidikan Tinggi. Yogyakarta: Kanisius.

Nugroho, Heru. 2001. Negara, Pasar, dan Keadilan Sosial. Yogyakarta: Pustaka Pelajar

O'neil, William F. 2002. Indeologi-ldeologi Pendidikan. Yogyakarta: Pustaka Pelajar.

Schroeder, Ralph, 2002, "Max Weber Tentang Hegemoni Sistem Kepercayaan", diterjemahkan oleh Ratna Noviani, Kanisius, Yogyakarta

Kompas, 08/09/2000

Kompas, 10/12/2007

Kompas, 24/07/2007

Kompas, 31/12/2007 